\title{
Notes on the Herring, Long-line, and Pilchard Fisheries of Plymouth during the Winter 1889-90.
}

\author{
By
}

\section{William Roach,}

Associate Member, Marine Biological Association, Plymouth.

\section{The Herring Fishery.}

[THE herring fishery is carried on at Plymouth during the winter months, when the adult herring seek the inshore waters for spawning. Besides these, however, the so-called "harbour herring" are taken in the summer and autumn; these appear to be the produce of the last spawning season, i.e. six months to a year old. $\mathrm{Mr}$. Cunningham has shown me specimens taken in the Cattewater in May, 1889, which vary from $3 \frac{1}{2}$ to 5 inches in length. Those which are at present being brought to the Laboratory (September, 1890) are 9 or 10 inches in length, but their reproductive organs are still at an extremely early stage of development. Further observations on these harbour herring are much needed, and are being gradually made.

The nets used up at Saltash for these harbour herring are, Mr. Roach informs me, used three to a boat, 7 score 7 meshes in depth and 44 fathoms to the rope, that is, 132 fathoms long, with buoylines 1 fathom deep. Those used in the Sound vary with the size of the boat. The smaller boats have two or three nets, $12-13$ score meshes in depth, and each 40-42 fathoms long; buoy-lines 4-5 fathoms apart, and 2 fathoms long; the latter are shortened up a fathom at low water. The boats used outside the Breakwater have three to four nets each, 13-14 score meshes deep. The next boats (9-ton dandy hookers, 36 feet long, 10 feet beam, worked by 4 men) use ten to twelve nets, 15-16 score meshes deep. The largest boats are decked, use sixteen to eighteen nets, 16-18 score meshes in depth, with 3-fathom buoy-lines; they are worked by 6 men. The proper herring mesh for full-roed fish is 
33 meshes to the yard. The Cawsand fishermen who fish in Cawsand and Whitsand Bays use moored nets.-G. H. FowLer.]

Note.-The symbol $>$ implies that the number given was the greatest catch by any single boat; a number without this implies the total amount of fish landed.

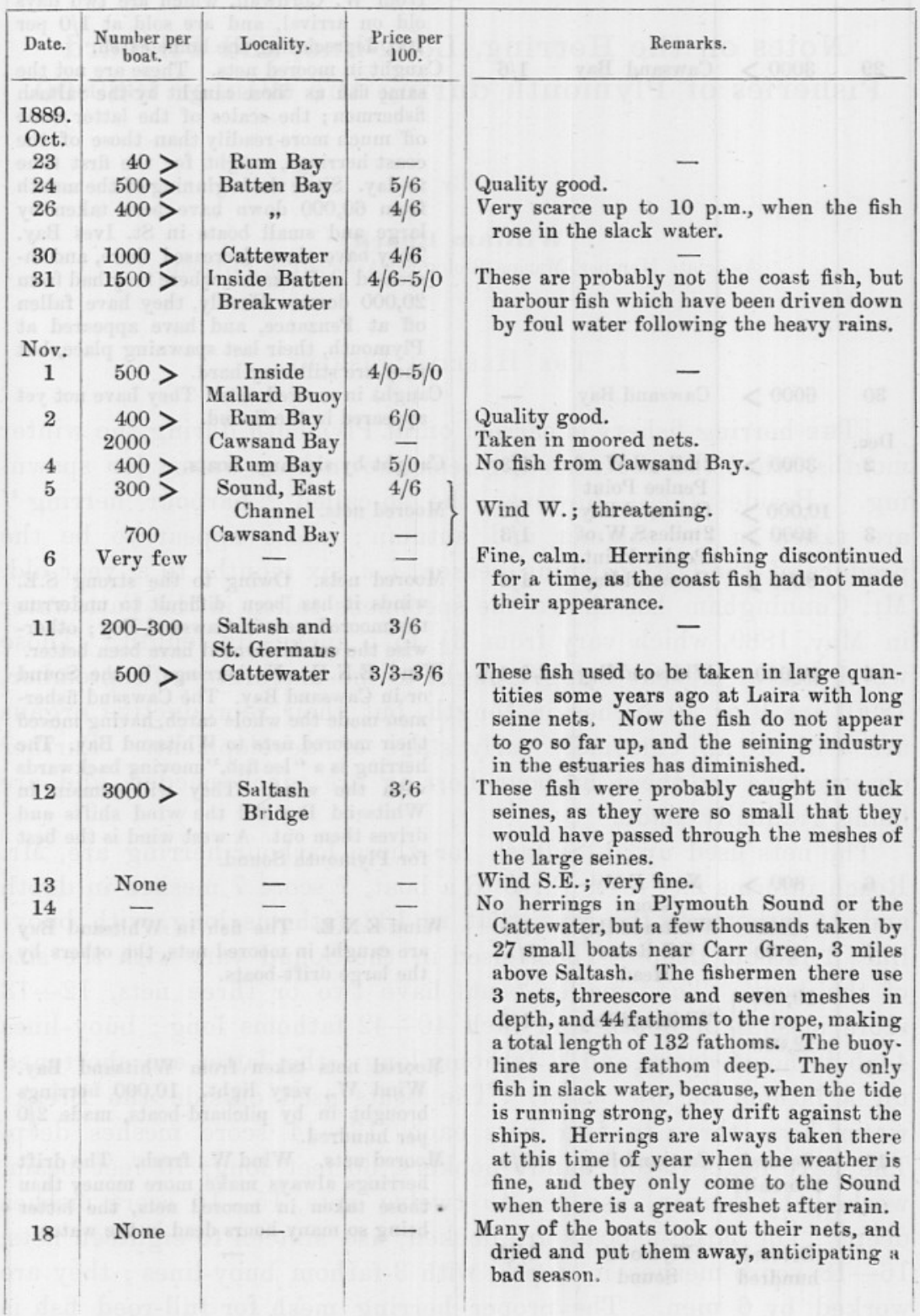




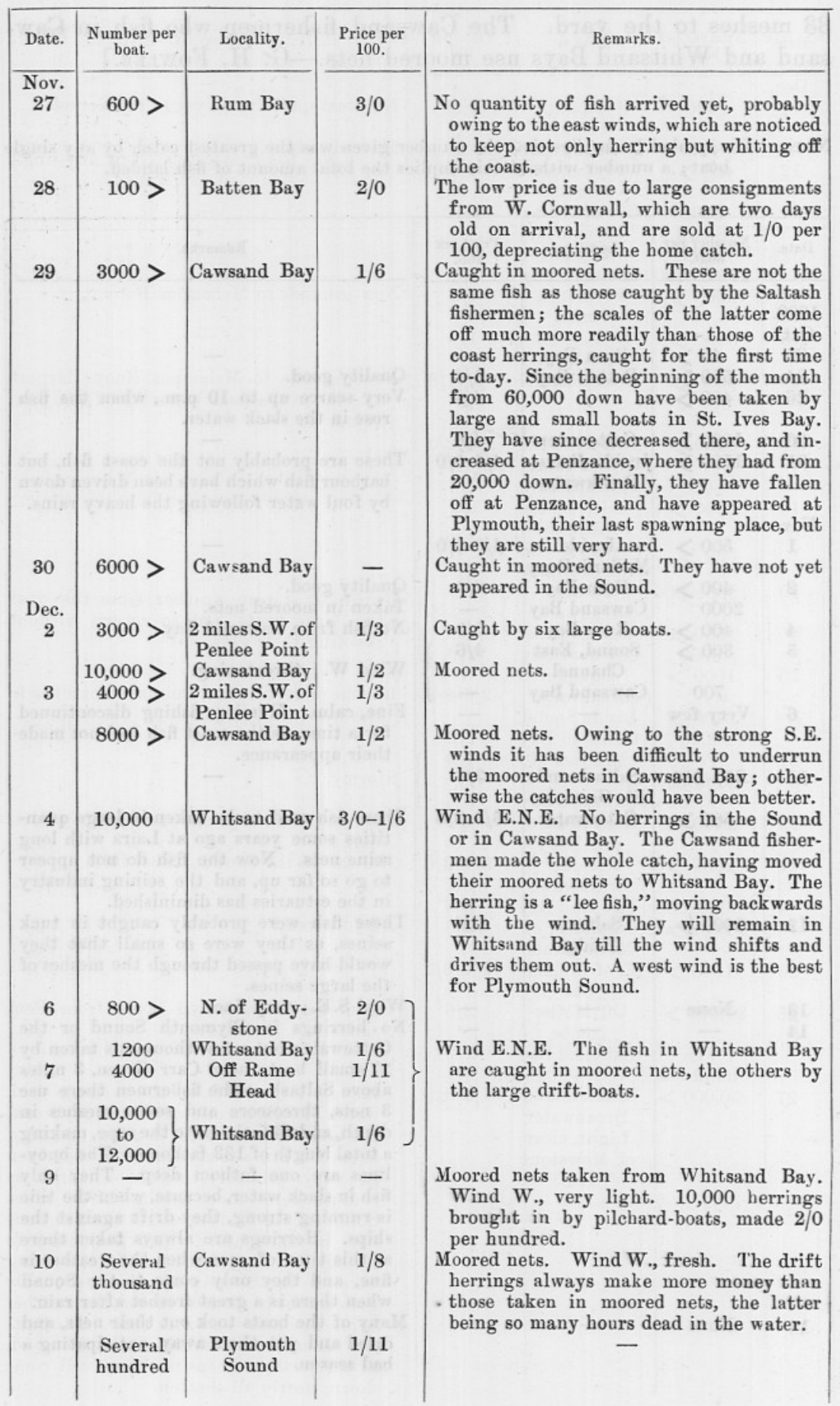


FISHERIES OF PLYMOUTH DURING THE WINTER 1889-90. 385

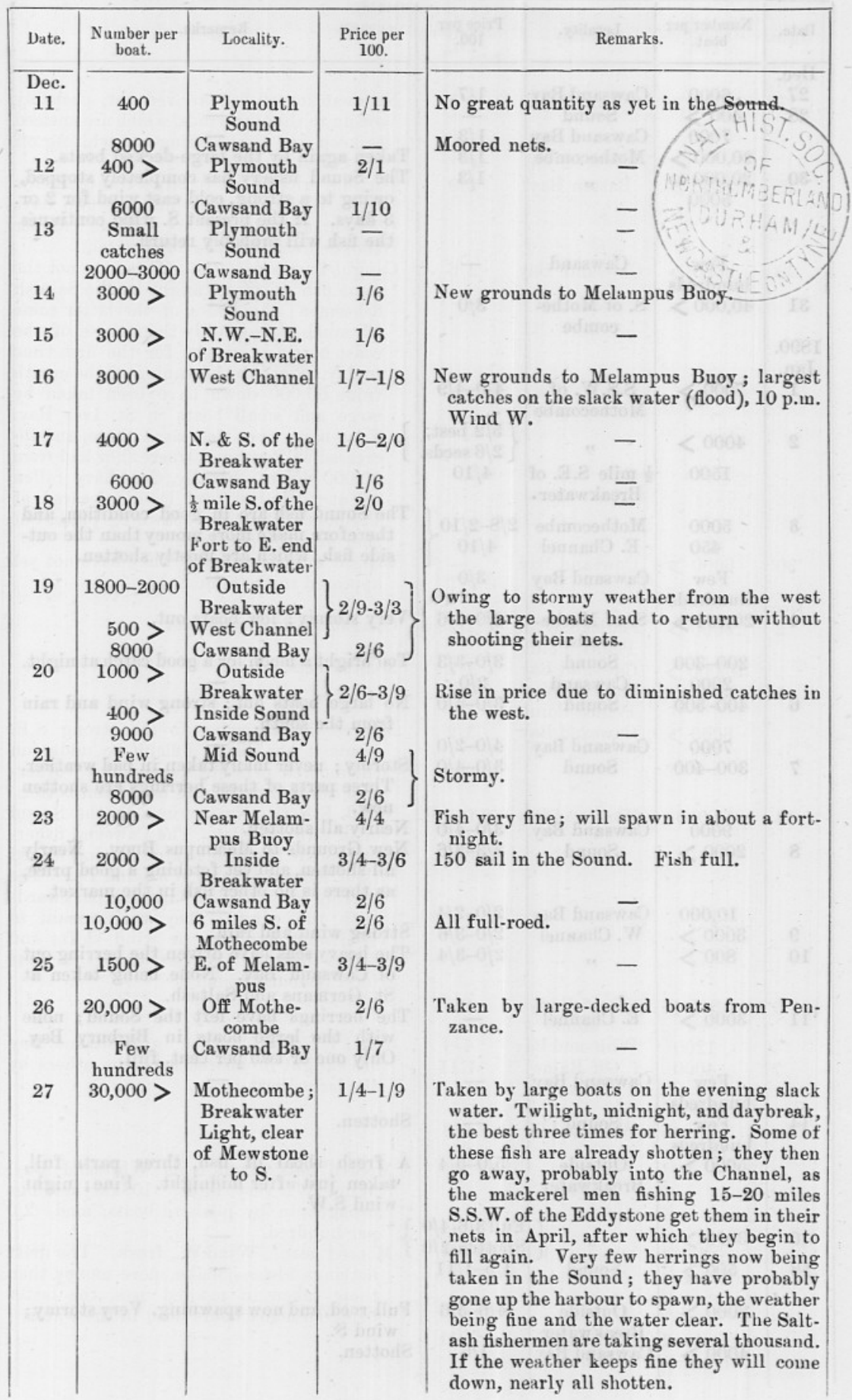




\begin{tabular}{|c|c|c|c|c|}
\hline Date. & $\begin{array}{l}\text { Number per } \\
\text { boat. }\end{array}$ & Locality. & $\begin{array}{l}\text { Price per } \\
100 .\end{array}$ & Remarks. \\
\hline \multirow{5}{*}{$\begin{array}{l}\text { Dec. } \\
27 \\
28\end{array}$} & & & & \\
\hline & 6000 & Cawsand Bay & $1 / 7$ & - \\
\hline & $400>$ & Sound & - & - \\
\hline & 7000 & Cawsand Bay & $1 / 3$ & M 1 \\
\hline & $20,000>$ & Mothecombe & $1 / 3$ & \multirow{2}{*}{$\begin{array}{l}\text { Taken again by the large-decked boats. } \\
\text { The Sound fishery has completely stopped, } \\
\text { owing to a strong, cold east wind for } 2 \text { or } \\
3 \text { days. If the present } \mathrm{S} \text {. wind continues } \\
\text { the fish will probably return. }\end{array}$} \\
\hline \multirow[t]{2}{*}{30} & $\begin{array}{l}20,000 \text { to } \\
5000\end{array}$ & " & $1 / 3$ & \\
\hline & $\begin{array}{l}\text { Few } \\
\text { hundreds }\end{array}$ & Cawsand & - & - \\
\hline 31 & $40,000>$ & $\begin{array}{l}\text { S. of Mothe- } \\
\text { combe }\end{array}$ & $3 / 0$ & - \\
\hline \multicolumn{5}{|l|}{1890.} \\
\hline 1 & 7000 & $\begin{array}{l}\text { S.S.W. of } \\
\text { Mothecombe }\end{array}$ & $4 / 0-4 / 9$ & - \\
\hline \multirow[t]{2}{*}{2} & $4000>$ & , & $\left\{\begin{array}{l}5 / 2 \text { best, } \\
2 / 6 \text { secds. }\end{array}\right.$ & 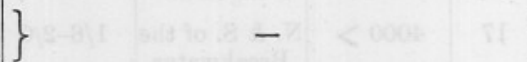 \\
\hline & 1500 & $\begin{array}{l}\frac{1}{2} \text { mile S.E. of } \\
\text { Breakwater }\end{array}$ & $4 / 10$ & 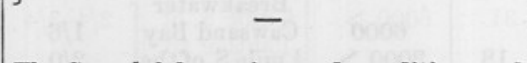 \\
\hline \multirow[t]{2}{*}{3} & $\begin{array}{r}5000 \\
450\end{array}$ & $\begin{array}{l}\text { Mothecombe } \\
\text { E. Channel }\end{array}$ & $\begin{array}{c}2 / 8-2 / 10 \\
4 / 10\end{array}$ & \multirow{2}{*}{$\begin{array}{l}\text { The Sound fish are in good condition, and } \\
\text { therefore make more money than the out- } \\
\text { side fish, which are mostly shotten. }\end{array}$} \\
\hline & Few & Cawsand Bay & $3 / 0$ & \\
\hline \multirow[t]{2}{*}{4} & $\begin{array}{l}\text { hundreds } \\
20,000>\end{array}$ & $\begin{array}{l}\text { S. of Mothe- } \\
\text { combe }\end{array}$ & $2 / 0-2 / 6$ & \multirow{2}{*}{$\begin{array}{l}\text { Very stormy; few boats out. } \\
\text { Too bright a moon for a good catch at night. }\end{array}$} \\
\hline & $\begin{array}{l}200-300 \\
2000\end{array}$ & $\begin{array}{l}\text { Sound } \\
\text { Cawsand }\end{array}$ & $\begin{array}{l}3 / 0-3 / 3 \\
2 / 0\end{array}$ & \\
\hline \multirow[t]{2}{*}{6} & $400-500$ & Sound & $3 / 0-4 / 0$ & $\begin{array}{l}\text { No large boats orit; strong wind and rain } \\
\text { from the south. }\end{array}$ \\
\hline & 7000 & Cawsand Bay & $4 / 0-2 / 0$ & \multirow[b]{2}{*}{$\begin{array}{l}\text { Stormy; never many taken in bad weather. } \\
\text { Three parts of these herrings are shotten } \\
\text { now. }\end{array}$} \\
\hline 7 & $300-400$ & Sound & $3 / 0-4 / 0$ & \\
\hline \multirow[t]{2}{*}{8} & $\stackrel{9000}{2000>}$ & $\begin{array}{l}\text { Cawsand Bay } \\
\text { Sound }\end{array}$ & $\begin{array}{l}3 / 0-4 / 0 \\
3 / 3-3 / 6\end{array}$ & $\begin{array}{l}\text { Nearly all shotten. } \\
\text { New Grounds to Melampus Buoy. Nearly } \\
\text { all shotten, and yet fetching a good price, } \\
\text { as there is no other fish in the market. }\end{array}$ \\
\hline & 10,000 & Cawsand Bay & $2 / 0-2 / 4$ & \multirow{4}{*}{$\begin{array}{l}\text { Strong wind and rain. } \\
\text { The heavy seas have driven the herring out } \\
\text { of Cawsand Bay. None being taken at, } \\
\text { St. Germans and Saltash. } \\
\text { The herrings have left the Sound; none } \\
\text { with the large boats in Bigbury Bay. } \\
\text { Only one or two per cent. full. }\end{array}$} \\
\hline 9 & $3000 \geq$ & W. Channel & $2 / 0-3 / 6$ & \\
\hline 10 & 800 & ", & $2 / 0-3 / 4$ & \\
\hline \multirow[t]{2}{*}{11} & $3000>$ & E. Channel & - & \\
\hline & $\begin{array}{l}\text { Few } \\
\text { hundreds }\end{array}$ & Cawsand Bay & - & - \\
\hline \multirow[t]{2}{*}{14} & $\begin{array}{l}\text { Few } \\
\text { hundreds }\end{array}$ & Sound & - & Shotten. \\
\hline & $5000>$ & $\begin{array}{l}\text { Outside } \\
\text { Breakwater }\end{array}$ & $5 / 0-5 / 4$ & $\begin{array}{l}\text { A fresh shoal of fish, three parts full, } \\
\text { taken just after miduight. Fine; night } \\
\text { wind S.W. }\end{array}$ \\
\hline 16 & $3000>$ &,$\quad\{$ & $\begin{array}{l}\text { Full } 3 / 6-4 / 0 \\
\text { Shotten } 2 / 0\end{array}$ & \\
\hline \multirow[t]{3}{*}{18} & $500>$ & Sound & $1 / 5-1 / 11$ & - \\
\hline & $2000>$ & $\begin{array}{c}\text { Outside } \\
\text { Breakwater }\end{array}$ & $4 / 6-5 / 6$ & \multirow{2}{*}{$\begin{array}{l}\text { Full-roed, and now spawning. Very stormy; } \\
\text { wind } \mathrm{S} \text {. } \\
\text { Shotten. }\end{array}$} \\
\hline & $4000>$ & Cawsand Bay & $1 / 6$ & \\
\hline
\end{tabular}


FISHERIES OF PLYMOUTH DURING THE WINTER 1889-90. 387

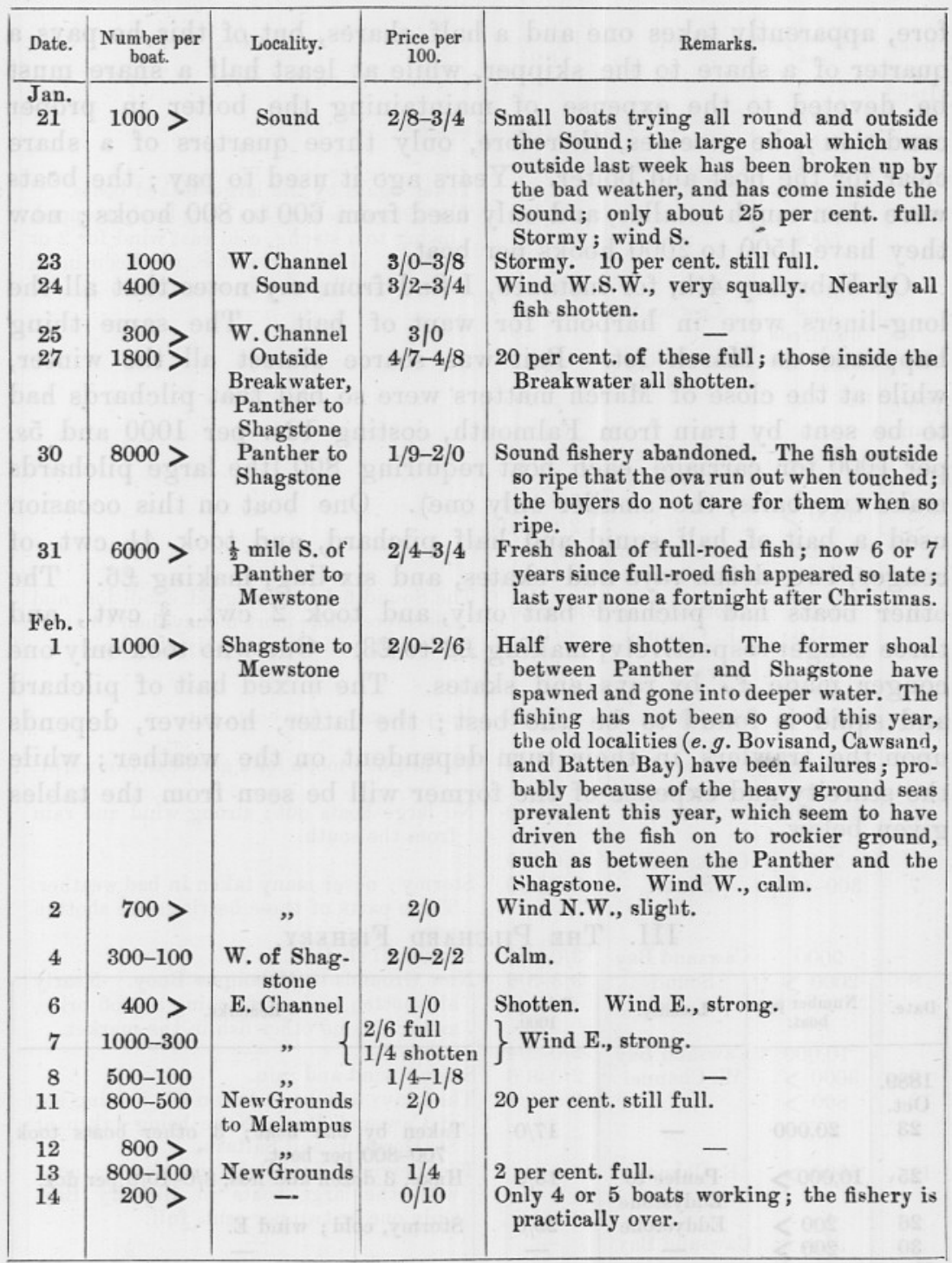

\section{The Long-Line Fishery.}

Long-lining no longer pays in this port, as there is so much time wasted in waiting for bait. The boats are worked by four men, and the profits are divided in five and a half shares, apportioned thus :To the four men one share each; to the owner, for the boat, one share; for the long-line or bolter a half-share. The owner, there- 
fore, apparently takes one and a half shares, but of this he pays a quarter of a share to the skipper, while at least half a share must be devoted to the expense of maintaining the bolter in proper condition; he receives, therefore, only three quarters of a share clear for the boat and bolter. Years ago it used to pay; the boats were then much smaller, and only used from 600 to 800 hooks; now they have 1500 to 2000 hooks per boat.

On February 4th, for instance, I find from my notes that all the long-liners were in harbour for want of bait. The same thing happened on March 1st. Bait was scarce almost all the winter, while at the close of March matters were so bad that pilchards had to be sent by train from Falmouth, costing $12 s$. per 1000 and $5 s$. per 1000 for carriage, each boat requiring 800 (the large pilchards make two baits, the smaller only one). One boat on this occasion used a bait of half squid and half pilchard, and took $4 \frac{1}{2} \mathrm{cwt}$. of conger, two dozen rays and skates, and six ling, making $\& 6$. The other boats had pilchard bait only, and took $2 \mathrm{cwt}$., $\frac{3}{4} \mathrm{cwt}$., and three conger respectively, making $£ 2$ to $£ 3$. One who took only one conger made $£ 7$ by rays and skates. The mixed bait of pilchard and squid is found to be the best; the latter, however, depends upon the trawlers, in their turn dependent on the weather; while the scarcity and expense of the former will be seen from the tables given below.

III. The Pilchard Fishery.

\begin{tabular}{|c|c|c|c|c|}
\hline Date. & $\begin{array}{c}\text { Number per } \\
\text { boat. }\end{array}$ & Locality. & $\begin{array}{l}\text { Price per } \\
1000 .\end{array}$ & Remarks. \\
\hline $\begin{array}{l}1889 . \\
\text { Oet. }\end{array}$ & & thing & ( & 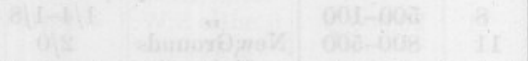 \\
\hline 23 & 20,000 & - & $17 / 0$ & $\begin{array}{l}\text { Taken by one boat; } 3 \text { other boats took } \\
700-800 \text { per bout. }\end{array}$ \\
\hline 25 & $10,000>$ & $\begin{array}{l}\text { Penlee to } \\
\text { Eddystone }\end{array}$ & $15 / 0$ & Hake, 3 dozen and less, $8 / 0-10 / 0$ per doz. \\
\hline $\begin{array}{l}26 \\
30\end{array}$ & $200>$ & Eddystone & $\underset{25 / 0}{-}$ & Stormy, cold; wind E. \\
\hline \multicolumn{5}{|l|}{ Nov. } \\
\hline 1 & $300>$ & $\begin{array}{l}\text { W. of Eddy- } \\
\text { stone }\end{array}$ & $25 / 0$ & 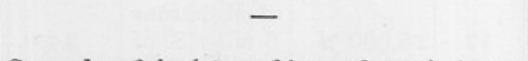 \\
\hline 5 & $8000>$ & " & $20 / 0$ & $\begin{array}{l}\text { Spur dog-fish (Acanthias vulgaris) innu- } \\
\text { merable, eating both fish and gear. }\end{array}$ \\
\hline 6 & - & I & - & $\begin{array}{l}\text { Very scarce, not enough for bait; } 3 \mathrm{doz} \\
\text { hake in } 15 \text { fath. }\end{array}$ \\
\hline 7 & $5000>$ & 5 miles outside & $11 / 0-15 / 0$ & 5-6 doz. hake, at $9 / 0$ per doz. \\
\hline $\begin{array}{l}8 \\
9\end{array}$ & $7000>$ & Outside Sound & $12 / 0$ & $7-8$ doz. hake, $9 / 0-9 / 6$. \\
\hline 9 & & $\begin{array}{l}\text { 4 miles outside } \\
\text { Breakwater }\end{array}$ & $10 / 0$ & Few doz. hake, at $8 j 0$ \\
\hline 11 & $20,000>$ & $\left|\begin{array}{c}10 \text { miles S. of } \\
\text { Plymouth }\end{array}\right|$ & $9 / 0-10 / 6$ & 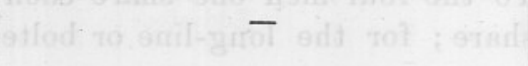 \\
\hline
\end{tabular}


FISHERIES OF PLYMOUTH DURING THE WINTER 1889-90. 389

\begin{tabular}{|c|c|c|c|c|}
\hline Date. & $\begin{array}{l}\text { Number per } \\
\text { boat. }\end{array}$ & Locality. & $\begin{array}{l}\text { Price per } \\
\quad 1000 .\end{array}$ & Remarks. \\
\hline $\begin{array}{l}\text { Nov. } \\
12\end{array}$ & $5000>$ & 2 miles $N$. of & $10 / 0$ & 114- \\
\hline 13 & $9000>$ & $\begin{array}{l}2 \text { miles N.W. } \\
\text { of Eddystone }\end{array}$ & $15 / 0-16 / 0$ & $\begin{array}{l}\text { Taken by Mevagissey boats. As the seine } \\
\text { fishery in the W. has so far proved a } \\
\text { failure, it is so much the better for the drift- } \\
\text { nets, as all the buyers are at Plymouth. }\end{array}$ \\
\hline 14 & $8000>$ & " & $15 / 0-16 / 0$ & $\begin{array}{l}\text { Good demand, as there are ships here } \\
\text { waiting to be loaded for W. Cornwall. }\end{array}$ \\
\hline 15 & $3000>$ & $\begin{array}{l}\text { E. of Eddy- } \\
\text { stone }\end{array}$ & $15 / 0-16 / 0$ & - \\
\hline 16 & $\begin{array}{c}\text { Few } \\
\text { hundreds }\end{array}$ & $\begin{array}{l}\text { N. of Eddy- } \\
\text { stone }\end{array}$ & $17 / 6$ & $\begin{array}{l}\text { Mostly purchased by the hook-and-line } \\
\text { whiting-boats, of which there are } 60-70 \\
\text { sail here. }\end{array}$ \\
\hline 18 & $1000>$ & $\begin{array}{l}6 \text { miles E. of } \\
\text { Eddystone }\end{array}$ & $15 / 0$ & 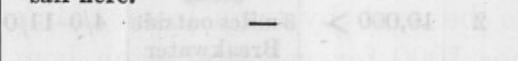 \\
\hline 19 & $1000>$ & - & - & $\begin{array}{l}\text { Very bad season; } 200 \text { sail of boats here, } \\
\text { the large boats taking out the pilchard- } \\
\text { nets, and substituting mackerel-nets. } \\
\text { Hake also fallen off; a W.S.W. wind } \\
\text { wanted, as the E. wind always keeps the } \\
\text { fish off this coast. }\end{array}$ \\
\hline 20 & $1000>$ & $\begin{array}{l}\text { E.S.E. of } \\
\text { Eddystone }\end{array}$ & $16 / 0$ & - \\
\hline 21 & $2000>$ & - & 一 & Most boats had no fish at all. \\
\hline 22 & Very scarce & 一 & 一 & $\begin{array}{l}\text { Three boats out of a hundred landed } 300 \\
\text { fish each. }\end{array}$ \\
\hline 29 & $5000>$ & $\begin{array}{l}\text { N.W. of } \\
\text { Eddystone }\end{array}$ & - & - \\
\hline $\begin{array}{c}30 \\
\text { Dec. }\end{array}$ & $2500>$ & $"$ & $17 / 6$ & 4.91 \\
\hline 2 & $8000>$ & $\begin{array}{l}5 \text { miles S.W. } \\
\text { of Penlee }\end{array}$ & $17 / 6$ & - \\
\hline 3 & $15,000>$ & $\begin{array}{l}2 \text { miles outside } \\
\text { Eddystone }\end{array}$ & $16 / 6$ & Only 8 boats with good catches. \\
\hline 6 & $800>$ & $\begin{array}{l}\text { N.W̆. of } \\
\text { Eddystone }\end{array}$ & $17 / 4$ & 8 boats. \\
\hline 7 & $\begin{array}{c}\text { Few } \\
\text { hundreds }\end{array}$ & - & - & - \\
\hline 10 & 10,000 & $\begin{array}{l}4 \text { miles S. of } \\
\text { Rame Head }\end{array}$ & $17 / 0$ & - \\
\hline 11 & $20,000>$ & $\begin{array}{l}6 \text { miles S.W. } \\
\text { of Penlee }\end{array}$ & $17 / 0$ & - \\
\hline 12 & 5000 & " & $17 / 6$ & - \\
\hline 13 & $\begin{array}{c}\text { Few } \\
\text { hundreds }\end{array}$ & - & - & - \\
\hline 14 & $30,000>$ & $\begin{array}{l}\text { Between } \\
\text { Penlee and } \\
\text { Eddystone }\end{array}$ & $11 / 0-16 / 6$ & - \\
\hline 16 & $15,000>$ & $\begin{array}{l}8-10 \text { miles } \mathrm{S} . \\
\text { of Mewstone }\end{array}$ & $15 / 0$ & - \\
\hline 17 & $25,000>$ & $\begin{array}{l}6 \text { miles } \mathrm{S} . \text { of } \\
\text { Stroke Pt. }\end{array}$ & $14 / 0$ & - \\
\hline 18 & $15,000>$ & - & $13 / 0-15 / 0$ & - \\
\hline 21 & $\begin{array}{l}20,000- \\
10,000\end{array}$ & - & $17 / 0$ & $\begin{array}{l}\text { Only } 4 \text { boats out, the weather being so bad } \\
\text { from } \mathrm{S} \text {. W. They saw what almost always } \\
\text { indicates a good catch, viz. the gannets } \\
\text { diving from a great height. }\end{array}$ \\
\hline 24 & 17,000 & 2 miles N.W. & $14 / 0-15 / 0$ & Very stormy. \\
\hline 26 & $20,000>$ & $\begin{array}{r}\text { Rame Head } \\
\text { to Eddystone }\end{array}$ & $14 / 0-15 / 0$ & 20 boats. \\
\hline
\end{tabular}


390 HERRING, LONG-LINE, AND PILCHARD FISHERIES OF PLYMOUTH.

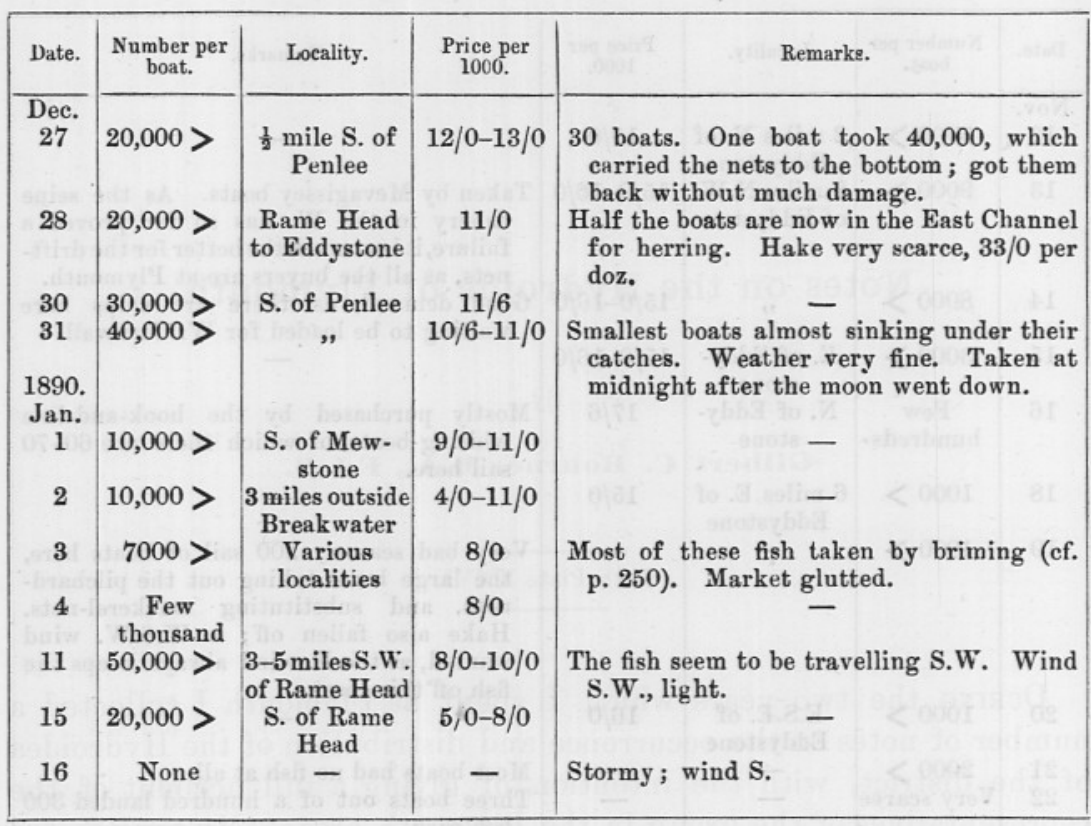

[These extremely valuable notes will be continued in the next number of the Journal.-G. H. F.] 